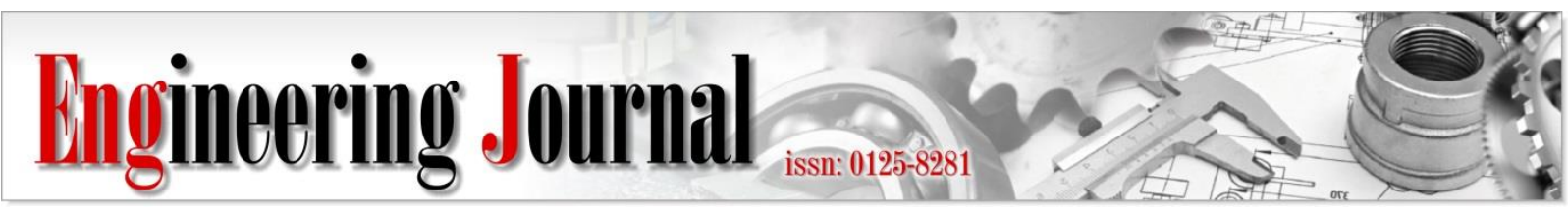

Article

\title{
Improvement in Photocatalytic Effects of Dye Sensitized Titanium Dioxide by Hydroxyapatite Coating
}

\author{
Htoo Nay Wunn , Shinichi Motoda ${ }^{\mathrm{b}, *}$, Motoaki Morita, and Shinya Katayose \\ Tokyo University of Marine Science and Technology, 2-1-6 Etchujima, Koto-ku, Tokyo, 135-8533, Japan \\ E-mail: ad182007@edu.kaiyodai.ac.jp, bmotoda@kaiyodai.ac.jp (Corresponding author)
}

\begin{abstract}
Applying photocatalytic n-semiconductor effect of titanium dioxide, performance of $\mathrm{TiO}_{2}$ anode with copper oxides cathode as a wet solar cell in seawater is being studied. This research aimed to study photocatalytic effects of dye sensitized $\mathrm{TiO}_{2}$ electrode coated by hydroxyapatite (HAp). $\mathrm{TiO}_{2}$ electrode was manufactured double layered by screen printing method and copper oxides electrode by vacuum deposition on Type 329J4L stainless steel base substrate. N719 Ruthenizer dye was used for sensitizing on $\mathrm{TiO}_{2}$ electrode and HAp was coated on the electrode surface by squeegee printing method. Four types of $\mathrm{TiO}_{2}$ electrodes were studied; $\mathrm{TiO}_{2}$ electrode, dye-sensitized $\mathrm{TiO}_{2}, \mathrm{HAp}$ coated $\mathrm{TiO}_{2}$, and dye-sensitized $\mathrm{TiO}_{2}$ with $\mathrm{HAp}$ coating. Cell voltage and current density was measured under irradiated and dark conditions. The power densities of electrode with HAp coating was found higher than other electrodes without HAp. The current flow was enhanced by introducing HAp coating while dye sensitizing reduced current flow. Cyclic voltammetry (CV) and Electrochemical Impedance Spectroscopy (EIS) analysis were performed. EIS analysis showed HAp coating increased capacitance values of each electrodes. The surface of electrodes analysed by Scanning Electron Microscope (SEM) and Electron Dispersion X-ray Spectroscopy (EDS) indicated that HAp was dispersed on $\mathrm{TiO}_{2}$ surface but was not formed as a layer.
\end{abstract}

Keywords: Titanium dioxide, hydroxyapatite, cyclic voltammetry, EIS analysis.

ENGINEERING JOURNAL Volume 24 Issue 4

Received 6 May 2020

Accepted 2 June 2020

Published 31 July 2020

Online at http://www.engj.org/

DOI:10.4186/ej.2020.24.4.63 


\section{Introduction}

Due to excess release of greenhouse gases from fossil related industries, we have been facing global warming for decades which leads to climate change across the world. On the other hand, energy security is vitally important for the development of all nations to their respective goals. In order to achieve those targets, we have been searching for alternative ways of energy sources which are renewable and sustainable, and lead to zero harmful gas emissions and the least application of land resources for civilization. To meet those requirements, we have been conducting a research concerning a wet solar cell using two photocatalytic semiconductors with seawater electrolyte that is aimed to be used in marine environment [1-7]. This wet solar cell composed of two photo electrodes: n-type photocatalytic semiconductor titanium dioxide anode and p-type photocatalytic semiconductor copper oxides cathode [8].

Dye sensitizing on $\mathrm{TiO}_{2}$ electrode in this cell was introduced based on the principle of Dye sensitized Solar Cell (DSSC) [9-11, 13]. Ruthenium complex commonly known as N719 is used as a dye for sensitizing the anode. Hydroxyapatite (HAp) is used for anchorage between $\mathrm{TiO}_{2}$ layer and $\mathrm{Ru}$. Hydroxyapatite $\left(\mathrm{Ca}_{10}\left(\mathrm{PO}_{4}\right)_{6}(\mathrm{OH})_{2}\right)$ is being researched for its good biocompatibility $[12,21]$. We did choose HAp not only for its high binding affinity with $\mathrm{Ru}$ complexes but also its biocompatibility not to get harmful effect on marine and aquatic species when the cell is deployed in marine environment. The schematic representation of this solar cell is shown in Fig. 1.

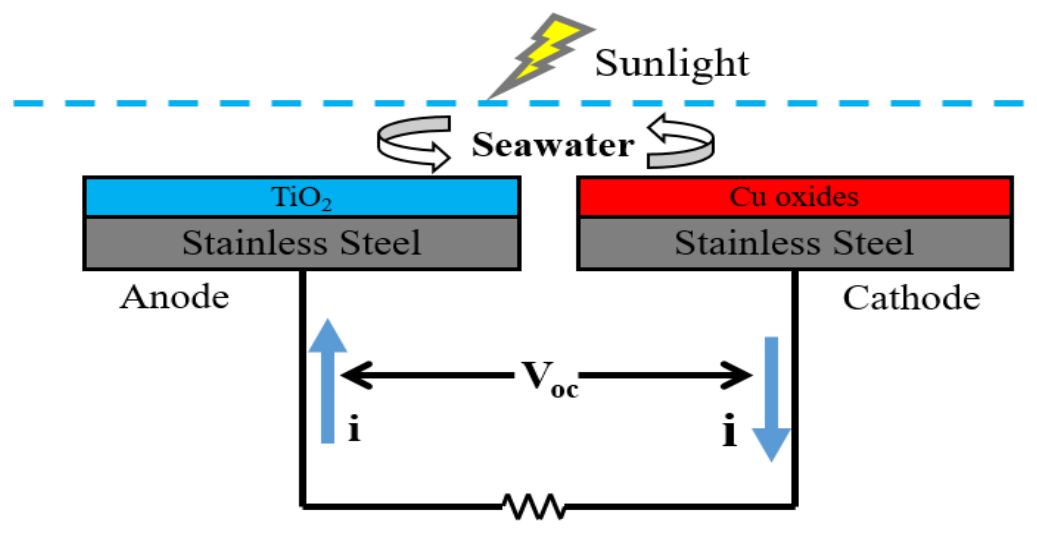

Fig. 1. Schematic representation of $\mathrm{TiO}_{2}$ vs $\mathrm{Cu}$ oxides solar cell.

\section{Experimental}

\subsection{Preparation of Sample Electrodes}

\subsubsection{Preparation of $\mathrm{TiO}_{2}$ electrodes}

Double layered Titanium dioxide $\left(\mathrm{TiO}_{2}\right)$ film was screen printed onto ultrasonically cleaned and passivated $4 \mathrm{~mm} \times 4 \mathrm{~mm}(1 \mathrm{~mm}$ in thickness) stainless steel substrate (Type 329J4L) with heat treatment temperatures of 150 ${ }^{\circ} \mathrm{C}$ (60 minutes) for first layer and $550{ }^{\circ} \mathrm{C}$ (30 minutes) for second layer $[14,18]$. Four types of $\mathrm{TiO}_{2}$ electrodes were prepared for the experiment as the followings;

1. Double layered $\mathrm{TiO}_{2}$ electrode $\left(\mathrm{TiO}_{2}\right)$

2. Dye-sensitized double layered $\mathrm{TiO}_{2}$ electrode $\left(\mathrm{TiO}_{2}, \mathrm{Ru}\right)$

3. Double layered $\mathrm{TiO}_{2}$ electrode coated by Hydroxyapatite $\left(\mathrm{TiO}_{2}, \mathrm{HAp}\right)$, and

4. Dye-sensitized double layered $\mathrm{TiO}_{2}$ electrode with Hydroxyapatite coating $\left(\mathrm{TiO}_{2}, \mathrm{Ru} \& \mathrm{HAp}\right)$. After that, the electrodes were epoxy coated and solder welded ready for the experiment.

Dye-sensitizing was performed by immersing the electrodes in ruthenium complex $(\mathrm{Ru})$ solution for 10 hours. Ru solution was prepared by dissolving ruthenium complex $(4 \mathrm{mg})$ in the solutions of acetonitrile $(250 \mathrm{mg})$ and t-butyl alcohol (250 mg).

Hydroxyapatite paste was coated on the electrodes by manual squeegee method. After which, the HAp coated electrodes were heat-treated at $150{ }^{\circ} \mathrm{C}$ for 60 minutes. HAp paste was prepared by mixing HAp powder with Carboxylmethyl Cellulose (CMC) and adding them in the solution of ethanol and water. The paste was ultrasonically mixed to get distributed and good viscosity of the paste. The surface of $\mathrm{TiO}_{2}$ electrode changed when $\mathrm{Ru}$ was sensitized. The surface color of $\mathrm{TiO}_{2}$ electrode did not change after HAp coating but the surface roughness has changed so that rougher surface appeared after HAp coating as in Fig. 2.

\subsubsection{Preparation of copper oxides electrodes}

Firstly, copper film was formed on the passivated stainless steel substrate (same specification as the substrate for $\mathrm{TiO}_{2}$ electrode) by vacuum vapor deposition. Copper deposited substrate is then heat-treated at $350{ }^{\circ} \mathrm{C}$ in muffle furnace for 30 minutes to form copper oxides layer (Copper (I) oxide $\left(\mathrm{Cu}_{2} \mathrm{O}\right)$ and Copper (II) oxide $(\mathrm{CuO}))$. The images of the surface of copper oxides electrode and four types of $\mathrm{TiO}_{2}$ electrode are shown in Fig. 2. 


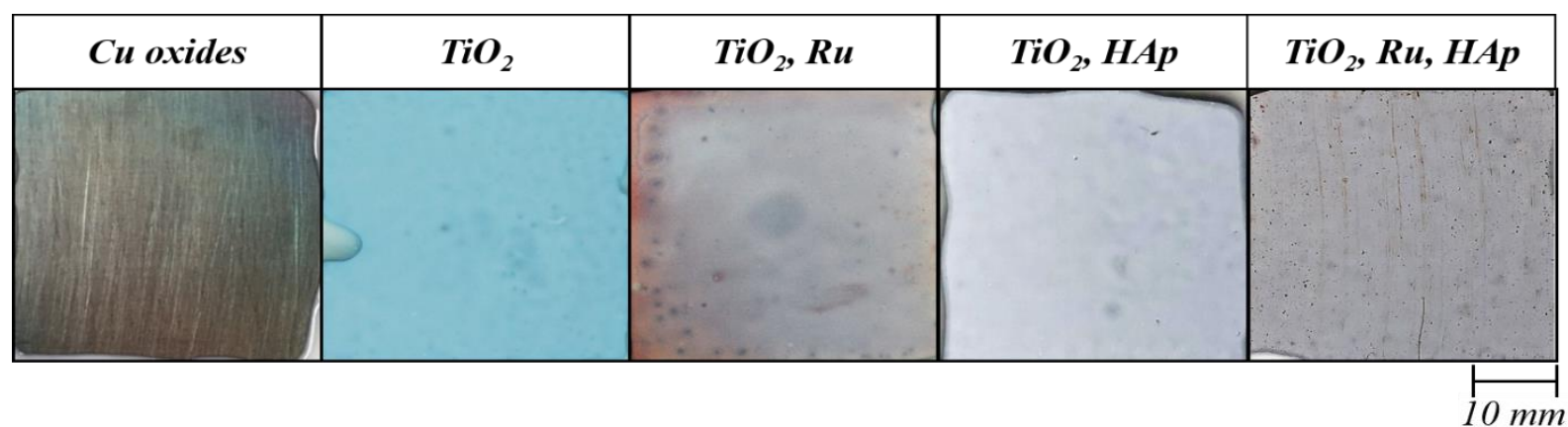

Fig. 2. Optical images of surfaces of four types of $\mathrm{TiO}_{2}$ electrodes and Copper oxides electrode.

\subsection{Measurements}

2.2.1. Power density versus cell voltage measurement (PV)

The power density of the cell was performed in order to get the power out of the cell, and to compare power conversion efficiency of the cells with different electrodes. The electrodes were immersed in a container with two transparent glasses which was filled with about 1.5 liters of artificial seawater (ASW). The electrodes were immersed in ASW against Xenon lamp. The lamp was calibrated so that the light intensity was $10.5 \mathrm{~mW} / \mathrm{cm}^{2}$ with a wavelength range of $250 \mathrm{~nm}$ to $800 \mathrm{~nm}$. The power density was measured between $\mathrm{TiO}_{2}$ electrode and $\mathrm{Cu}$ oxides electrode by the Potentiostat. The measurement was performed in both irradiated condition and dark condition. The voltage swapped from open circuit voltage to short circuit voltage for both conditions. For irradiation condition, the power density of the cell constructed by $\mathrm{TiO}_{2}$ electrode and platinum counter electrode was also measured to make a comparison between the power density of the cell with $\mathrm{TiO}_{2}$ and $\mathrm{Cu}$ oxides. Figure 3 shows the power density vs cell voltage measurement of the cell.

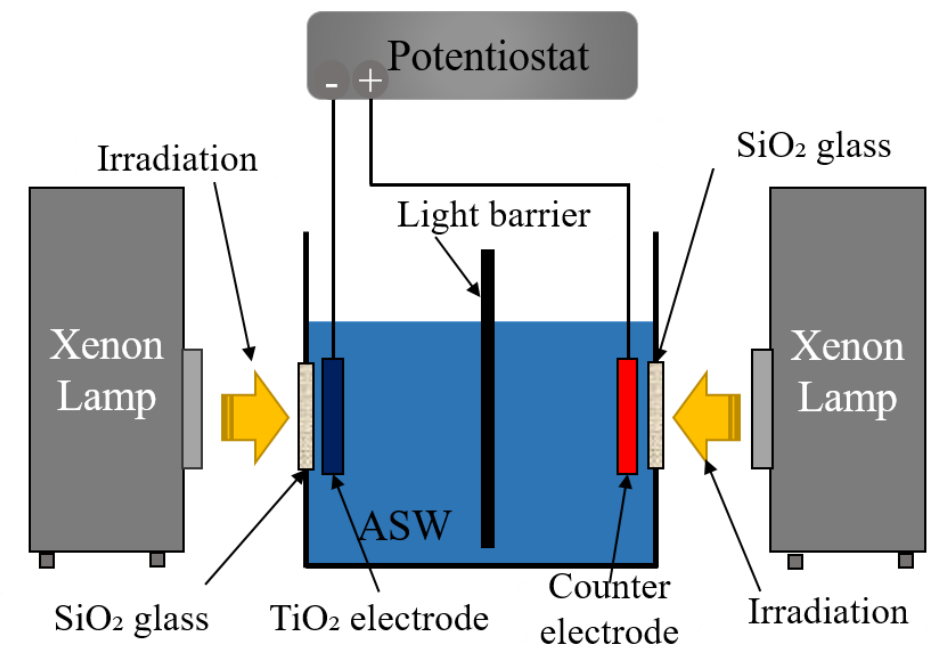

Fig. 3. Schematic representation of power density vs cell voltage measurement.

\subsubsection{Cyclic voltammetry measurement (CV)}

The CV measurement was carried out to understand more about the electrochemical behavior of the electrodes based on the past study of photopotential and polarization characteristics of the electrodes. Cyclic voltammetry measurement of four types of $\mathrm{TiO}_{2}$ electrode was performed in both dark and irradiated conditions in artificial seawater by the Potentiostat. The lamp with the same specification as in power density measurement was used for irradiation. The voltage was swapped upward in first sweep and downward in second sweep without delay time at turning point.

\subsubsection{Electrochemical impedance measurement (EIS)}

Electrochemical Impedance Spectroscopy (EIS) analysis was performed to better understand the surface of the electrodes [16, 17, 19]. EIS for four types of $\mathrm{TiO}_{2}$ electrode was conducted in irradiated condition with artificial seawater as the electrolyte. The measurement was performed by the Electrochemical Analyzer connected with the Frequency Response Analyzer. The base current was set from Tafel regions and additional current is $10 \%$ of the base current. The frequency was set to decrease from $100 \mathrm{kHz}$ to $1 \mathrm{mHz}$. From the results gained, an 
equivalent circuit was constructed by curve fitting and the impedance values were extracted [20].

\subsubsection{Surface analysis}

The surface of the electrodes were observed by Scanning Electron Microscopy and Electron Dispersion X-ray Spectroscopy (EDS) in order to get the surface characteristics of the electrodes and the effect of HAp coating on the surface of the electrode. From the results of EIS, it is better to understand the electrode surface combined with SEM and EDS results. The surface of each electrode before and after irradiated P-V measurement of $\mathrm{TiO}_{2}$ vs $\mathrm{Cu}$ oxides cell was examined with SEM and the composition was calculated by EDS. The effect of HAp coating was examined by SEM and EDS.

\section{Results and Discussions}

\subsection{Power Density Measurement of the Cell}

Figure 4 shows the graphs for power density vs cell voltage measurement of $\mathrm{TiO}_{2}$ vs $\mathrm{Cu}$ oxides cell and $\mathrm{TiO}_{2}$ vs Platinum cell. In all conditions, power densities of the cells with electrodes containing HAp showed higher than those without HAp. They also showed wider voltage range in both conditions. On the other hand, power profile of electrodes with $\mathrm{Ru}$ showed narrow voltage range and lower power density output. Maximum power density of the cell with $\mathrm{TiO}_{2}$ and HAp is approximately 4 times higher than that of $\mathrm{TiO}_{2}$ and $\mathrm{Ru}$. We can see clearly that the photocatalytic effect of $\mathrm{TiO}_{2}$ was drastically suppressed by the use of ruthenium complex sensitizing. This is considered to be the absence of redox couples in the electrolyte (ASW) for good matching required to reduce the oxidized dye while the light was irradiated. In the case of darkness, dye acts as the resistive bodies to the electrode. On the other hand, adding HAp increased the power density of the cell. The effect of coating HAp seems to increase the current flow of the electrode.

Power densities profile of $\mathrm{TiO}_{2}$ vs $\mathrm{Cu}$ oxides cells under irradiation is similar to that of $\mathrm{TiO}_{2}$ vs Platinum cell except in electrodes with $\mathrm{TiO}_{2}$ and HAp. This can be concluded that applying photocatalytic effects in both electrodes gives higher power/cost efficiency than $\mathrm{TiO}_{2}$ vs Platinum cell.

\subsection{Cyclic Voltammetry Measurement of $\mathrm{TiO}_{2}$ Electrode}

Figure 5 represents the graphs of double sweep cyclic voltammetry of different types of $\mathrm{TiO}_{2}$ electrodes in dark and under irradiation. From the measurement, the quasireversible region was studied. As we can see clearly, the area enclosed by $\mathrm{CV}$ curve in electrodes which contain HAp is wider than that of electrodes without HAp coating. On the contrast, the area bound by electrodes with $\mathrm{TiO}_{2}$ and $\mathrm{Ru}$ is the smallest among all electrodes. Regions bounded by curves of electrodes with HAp and
Ruthenizer were larger than curves of any other electrodes in irradiated condition. Since those areas are related to specific capacitance of electrode appeared in photocatalytic reaction, it is clear that coating HAp showed higher specific capacitance [15].

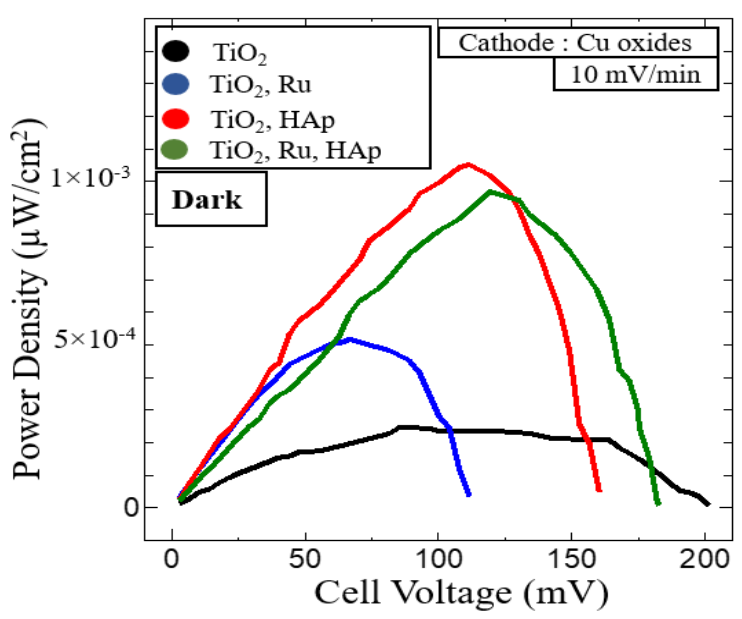

(a)

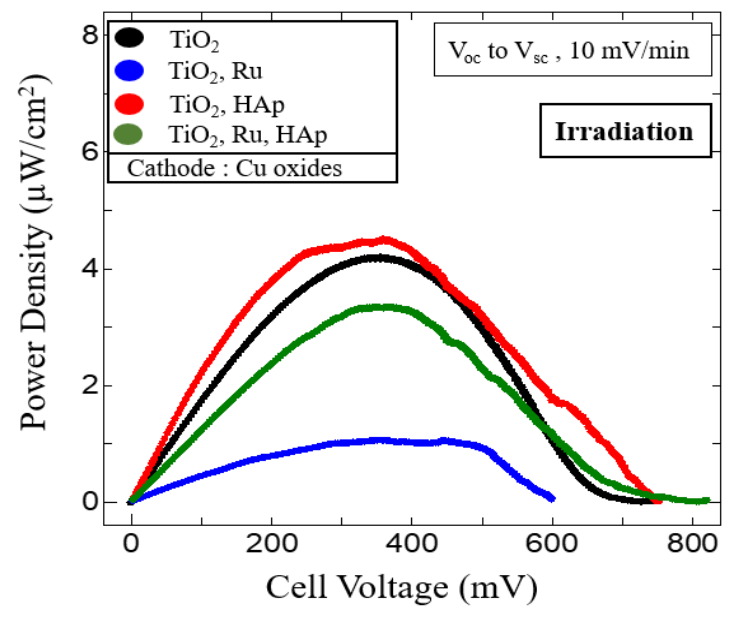

(b)

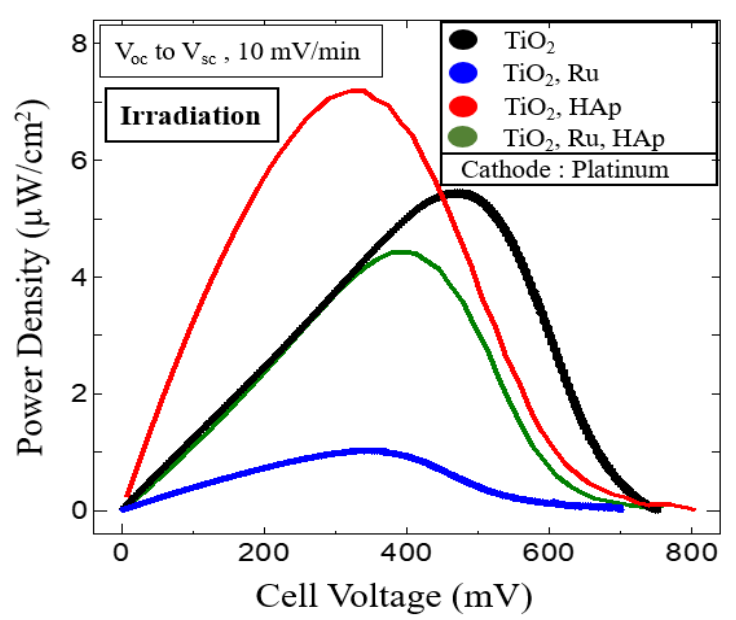

(c)

Fig. 4. P-V graphs of 4 types of $\mathrm{TiO}_{2}$ electrodes vs (a) $\mathrm{Cu}$ oxides electrode in dark, (b) $\mathrm{Cu}$ oxides electrode under irradiation, and (c) Platinum electrode under irradiation. 
This can be seen more in the following EIS measurement. On the other hand, Ru sensitizing is supposed to cause poor electron transfer between electrodes in the absence of enough redox electrolytes in ASW.

\subsection{Electrochemical Impedance Measurement, and Surface Analysis of $\mathrm{TiO}_{2}$ Electrodes}

3.3.1. Electrochemical impedance analysis (EIS) and equivalent circuit construction

From the EIS measurement, Cole-cole plot (Nyquist plot) was obtained for four different types of $\mathrm{TiO}_{2}$ electrodes in ASW under irradiation as shown in Fig. 6(a). $\mathrm{TiO}_{2}$ showed the lowest impedance values among all the electrodes. Adding Ru sensitizing to $\mathrm{TiO}_{2}$ electrode got the electrode become higher impedance values. Also, Adding HAp coating resulted in higher impedance mainly in lower frequencies regions. From the Cole-cole plot, a simple equivalent circuit for four types of electrodes was constructed by using curve fitting method. The equivalent circuit contains one solution resistance in series with 3 resistance-capacitance (RC) parallel components as shown in Fig. 6(b). From these, the impedance values were obtained. Table 1 shows the impedance values gained from curve fitting with respect to various electrodes.

From Table 1, it can be seen that electrode with $\mathrm{TiO}_{2}$ and $\mathrm{Ru}$ gave the highest impedance values in all $\mathrm{RC}$ parallel couples. Hence, it can be concluded that $\mathrm{Ru}$ acts as a barrier for electron transport in ASW as the electrolyte. It is not easy to distinguish layers of electrodes such as $\mathrm{TiO}_{2}$, $\mathrm{Ru}$ or HAp since $\mathrm{Ru}$ was dissolved into $\mathrm{TiO}_{2}$ layer and HAp did not form as a layer while it was coated on the surface of $\mathrm{TiO}_{2}$ layer. However, it is also not totally homogeneous with $\mathrm{TiO}_{2}$ particles. The electrode with $\mathrm{TiO}_{2}$ and HAp resulted in slightly higher capacitance values in RC 3 couples compared to that of $\mathrm{TiO}_{2}$ electrode. Adding HAp to $\mathrm{TiO}_{2}$ and $\mathrm{Ru}$ electrode increased the resistance value in $\mathrm{RC}$ parallel circuit 1 but it normalized the impedance values of other components.

\subsubsection{Surface analysis of the electrodes}

Figure 7 shows SEM images of HAp coated $\mathrm{TiO}_{2}$ electrode on the same region. From table 2, it can be seen that the chemical composition of elements (weight percent and atomic percent) on the surface of $\mathrm{HAp}$ coated $\mathrm{TiO}_{2}$ electrode taken from the same region with SEM images. From EDS analysis, the whole area constituted of mainly titanium and oxygen, but calcium and phosphorous which are the constituent of HAp were also found as the minor in the area. White regions on back scattered image represented Hap enriched region since $\mathrm{P}$ and $\mathrm{Ca}$ percentage is much higher than their surrounding areas. HAp particles were dispersed on the electrode. Although white regions are Hap enriched, other areas showed the presence of $\mathrm{P}$ and Ca. HAp coating did not form a layer on $\mathrm{TiO}_{2}$ film. Instead, Hap became partially homogeneous with $\mathrm{TiO}_{2}$ particles and some of them were dispersed as HAp enriched regions on the surface of $\mathrm{TiO}_{2}$ film. Dispersed HAp particles act as small capacitors on the electrode surface. Moreover, Presence of HAp regions increased capacitance of the electrode and also increased the current flow between electrolyte and electrode.

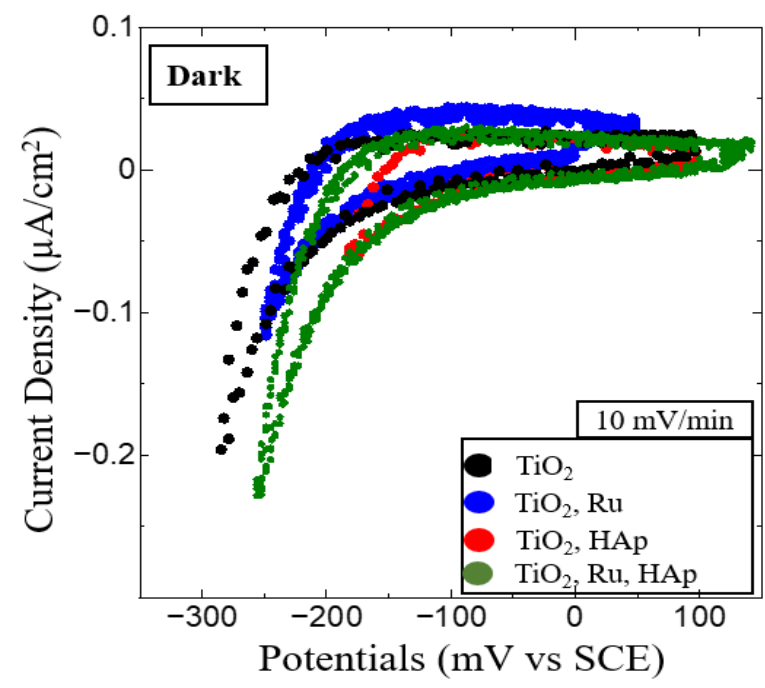

(a)

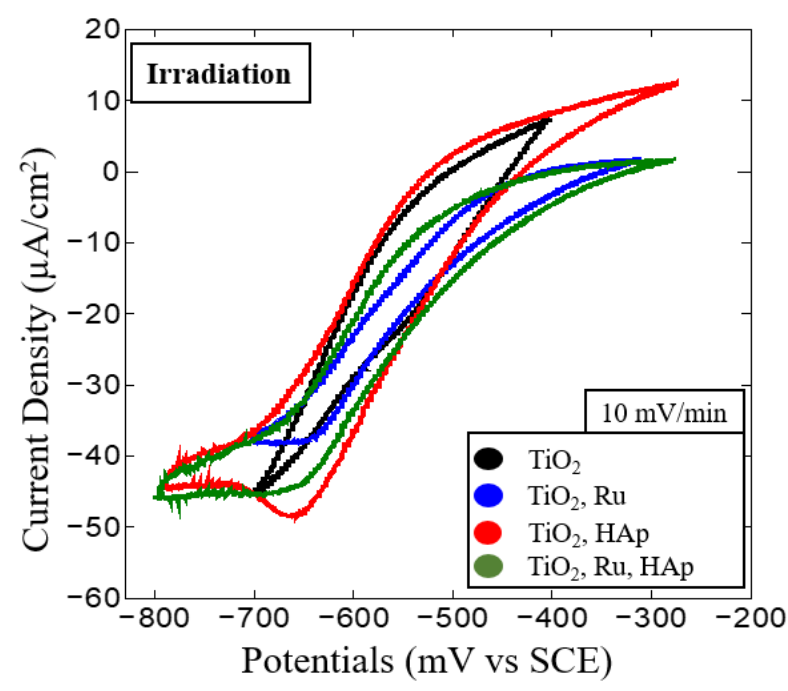

(b)

Fig. 5. Cyclic voltammetry measurement of different types of $\mathrm{TiO}_{2}$ electrodes (a) in dark condition, (b) under irradiation. 


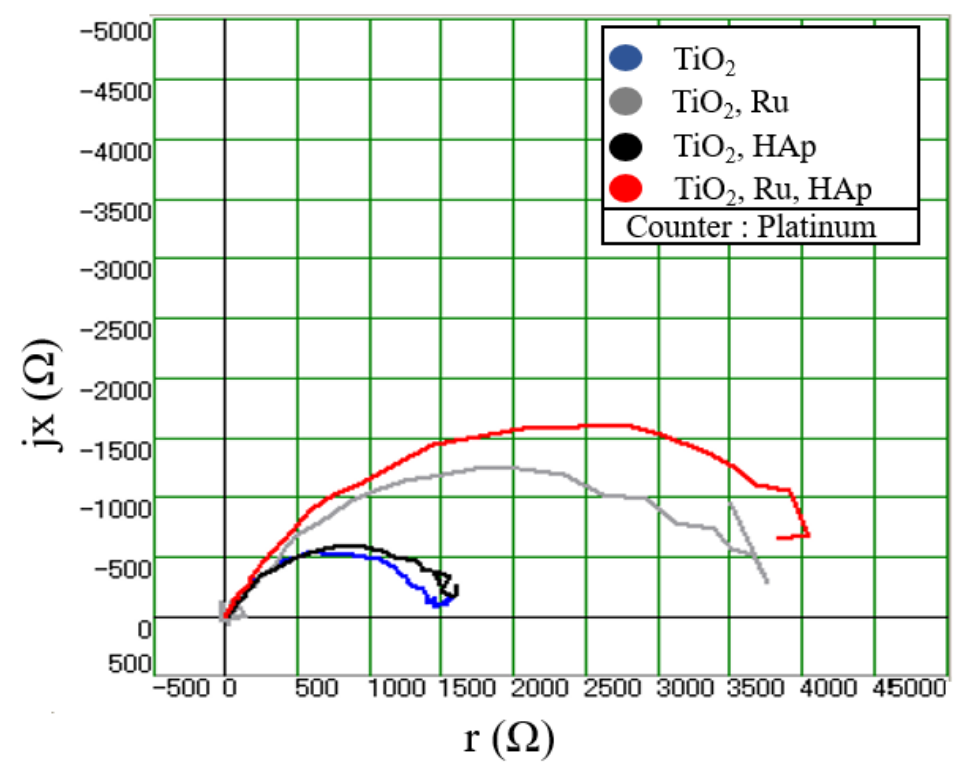

(a)

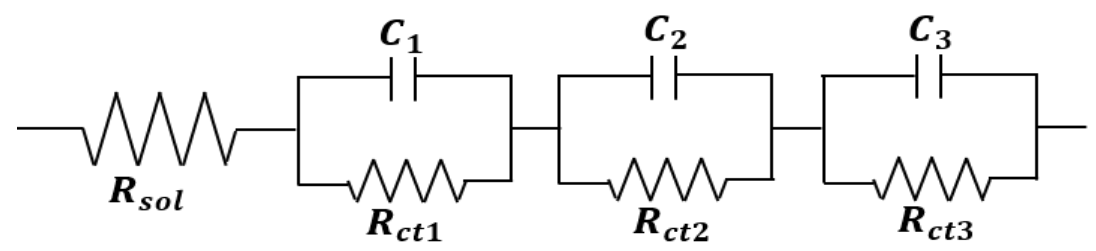

(b)

Fig. 6. Schematic representation of (a) Cole-cole plot of different types of $\mathrm{TiO}_{2}$ electrodes with platinum counter electrode, and (b) Equivalent circuit.

Table 1. Impedance values of electrodes gained from Cole-cole plot by curve fitting.

\begin{tabular}{l|c|cc|cc|cr}
\hline \multirow{2}{*}{$\begin{array}{l}\text { Types of } \\
\text { Electrodes }\end{array}$} & $\begin{array}{c}\text { Electrolyte } \\
\text { Resistance }\end{array}$ & \multicolumn{2}{|c|}{$\begin{array}{c}\text { RC parallel } \\
\text { circuit 1 }\end{array}$} & \multicolumn{2}{c|}{$\begin{array}{c}\text { RC parallel } \\
\text { circuit 2 }\end{array}$} & \multicolumn{2}{c}{$\begin{array}{c}\text { RC parallel } \\
\text { circuit 3 }\end{array}$} \\
\cline { 2 - 8 } & $\mathrm{R}_{\text {sol }}(\Omega)$ & $\mathrm{R}_{1}(\Omega)$ & $\mathrm{C}_{1}(\mathrm{mF})$ & $\mathrm{R}_{2}(\Omega)$ & $\mathrm{C}_{2}(\mathrm{mF})$ & $\mathrm{R}_{3}(\Omega)$ & $\mathrm{C}_{3}(\mathrm{mF})$ \\
\hline $\mathrm{TiO}_{2}$ & 13.76 & 1230 & 2.48 & 12.54 & 0.877 & 168.1 & 1.47 \\
$\mathrm{TiO}_{2}, \mathrm{Ru}$ & 45.92 & 2230 & 6.34 & 274.48 & 1.57 & 818.99 & 3.75 \\
$\mathrm{TiO}_{2}, \mathrm{HAp}$ & 28.71 & 1270 & 2.83 & 26.6 & 1.02 & 169.14 & 1.68 \\
$\mathrm{TiO}_{2}, \mathrm{Ru}, \mathrm{HAp}$ & 9.2 & 3270 & 5.43 & 83.42 & 0.972 & 779.82 & 2.42 \\
\hline
\end{tabular}

Table 2. Chemical composition of elements on the surface of $\mathrm{HAp}$ coated $\mathrm{TiO}_{2}$ electrode by EDS analysis (same region as the above SEM images).

\begin{tabular}{l|cc|cc|cr}
\hline \multirow{2}{*}{ Element } & \multicolumn{2}{|c|}{ HAp enriched } & \multicolumn{2}{|c|}{ TiO $_{2}$} & \multicolumn{2}{c}{ Whole region } \\
\cline { 2 - 7 } & Wt. $\%$ & At. $\%$ & Wt. $\%$ & At. $\%$ & Wt. $\%$ & At.\% \\
\hline Oxygen & 40.31 & 62.69 & 35.72 & 61.56 & 33.14 & 58.58 \\
Phosphorus & 12.92 & 10.38 & 2.63 & 2.35 & 2.38 & 2.18 \\
Calcium & 26.15 & 16.23 & 5.54 & 3.80 & 4.34 & 3.06 \\
Titanium & 20.62 & 10.70 & 56.11 & 32.29 & 59.06 & 34.86 \\
Sodium & - & - & - & - & 1.08 & 1.32 \\
\hline
\end{tabular}




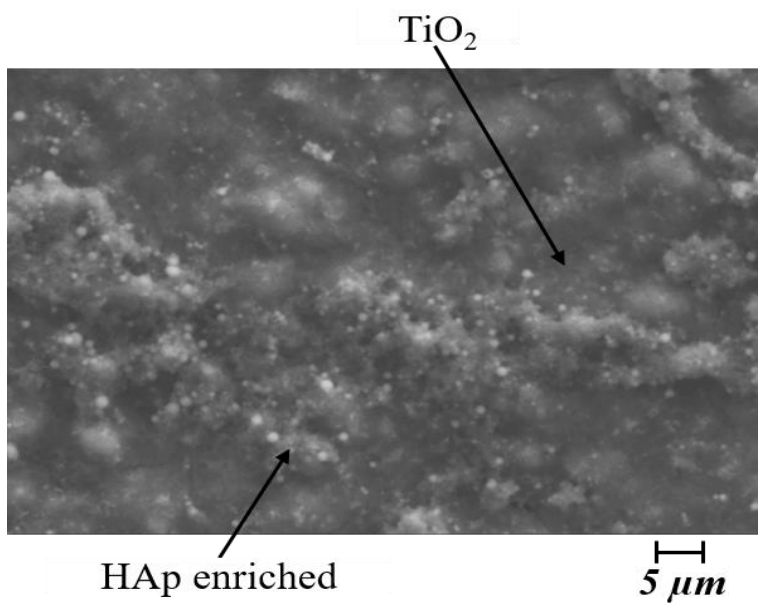

(a)

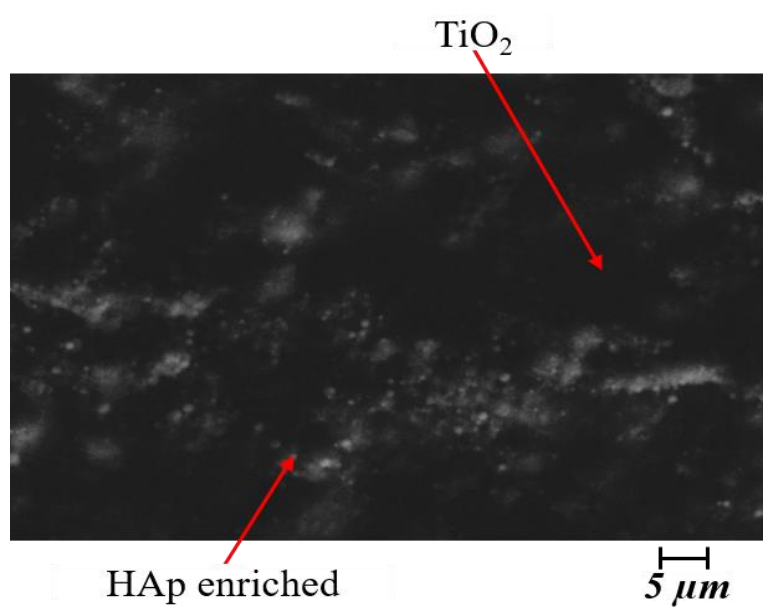

(b)

Fig. 7. (a) Secondary electron (SE) image, and (b) Back scattered electron (BSE) image, of the same region of HAp coated $\mathrm{TiO}_{2}$ electrode.

\section{Summary}

In this research, experiments such as P-V measurement, EIS analysis, SEM and EDS observation were carried out and the research is in progress aimed to enhance power density, material stability and durability of electrodes in the solar cell. From this current research, we can conclude that

1. Although $\mathrm{Ru}$ sensitizing suppresses the photocatalytic effect of $\mathrm{TiO}_{2}$ electrode and power output of the cell, HAp coating increases current density, and power density of the cell.

2. In cyclic voltammetry and power density measurements, the effect of semiconductor oxide layer cannot be seen in dark condition, the effects of HAp coating can be seen in both dark and irradiated conditions showing that HAp coating increases charge transfer in the electrode surface.

3. There is an increment in impedance values especially in capacitance, so this effect is considered to indicate the similar photocatalytic effect of $\mathrm{TiO}_{2}$ electrode as in $\mathrm{P}-\mathrm{V}$ and $\mathrm{CV}$ measurements.

4. The EIS, SEM and EDS analysis show that HAp is dispersed and partially homogenous in $\mathrm{TiO}_{2}$ layer without forming a distinct layer on top of $\mathrm{TiO}_{2}$ layer and coating HAp increases specific capacitance of $\mathrm{TiO}_{2}$ electrode and makes the effect of Ru sensitizing active.

\section{Acknowledgement}

This research work is partly supported by a Grant-inAid for Scientific Research from the Japan Society for the Promotion of Science (No.26281045).

\section{References}

[1] S. Motoda, M. J. Strom, and S. C. Dexter, "Power density profile of biofilm battery composed of stainless steel cathode and aluminum anode," ECS Transactions, vol. 16, no. 43, pp. 155-162, 2009.

[2] S. Motoda, M. J. Strom, and S. C. Dexter, "Power density profile of marine biofilm battery using a $\mathrm{TiO}_{2}$ anode," ECS Transactions, vol. 25, no. 35, pp. 3-1, 2010.

[3] S. Motoda, S. Uematsu, and T. Shinohara, "Influence of impurities in $\mathrm{TiO}_{2}$ coatings on electrode potential of photocatalytic anode assembling to marine microbial fuel cell," ECS Transactions, vol. 41, no. 31, pp. 129-136, 2012.

[4] S. Tamura, M. Morita, S. Motoda, S. Uematsu, and T. Shinohara, "Improvement in photo-potential characteristics of $\mathrm{TiO}_{2}$ electrode assembling to marine microbial fuel cell," ECS Transactions, vol. 58, no. 30, pp. 39-46, 2014.

[5] F. Watanabe, S. Motoda, and M. Morita, "Photopotential property of $\mathrm{TiO}_{2}$ electrode prepared by the screening printing method," ECS Transactions, vol. 75, no. 18, pp. 93-100, 2017.

[6] H. Nay Wunn, S. Motoda, and M. Morita, "Photopotential and polarization characteristics of ruthenizer complex sensitized $\mathrm{TiO}_{2}$ electrode for marine microbial fuel cell," ECS Transactions, vol. 80, no. 10, pp. 65-73, 2017.

[7] H. Nay Wunn, H. Tanifuji, S. Motoda, and M. Morita, "Devising the specification of a solar cell utilizing $\mathrm{TiO}_{2}$ photoanode and copper oxides photocathode," ECS Transactions, vol. 86, no. 2, pp.59-39, 2018.

[8] M. Morita, K. Kishihara, S. Motoda, N. Koga, and T. Shinohara, "Effect of oxidation temperature on phot-catalytic properties of stainless steel coated by copper oxide," ISIJ International, vol. 57, no. 9, pp.1609-1616, 2017.

[9] K. Kalyanasundaram, "Photochemical and photoclectrochemical approaches to energy conversion," in Dye-Sensitized Solar Cells. France: CRC Press Inc., 2010, pp. 1-32. 
[10] M. Grätzel, "Dye-sensitized solar cells," Journal of Photochemistry and Photobiology C, vol. 4, pp. 145-153, 2003.

[11] A. A. El Hadad, E. Peón, F. R. García-Galván, V. Barranco, J. Parra, A. Jiménez-Morales, and J. C. Galván, "Biocompatibility and corrosion protection behaviour of hydroxyapatite Sol-gel-derived coatings on Ti6Al4V alloy," Materials, vol. 10, no. 2, 2017.

[12] Z. Yu, "Liquid redox electrolytes for dye-sensitized solar cells," doctoral thesis, KTH Chemical Science and Engineering, Royal Institute of Technology, Stockholm, Sweden, 2012.

[13] A. Gagliardi, M. Auf der Maur, and A. Di Carlo, "Theoretical moddeling of dye sensitized solar cells: A challenging issue," in Dye-sensitized Solar Cells and Solar Cell Performance. New York: Nova Science Publishers, 2012.

[14] Solaronix, "Solaronix materials," Solaronix SA Switzerland. [Online]. Available: https://www.solaronix.com/documents/solaronix_ materials.pdf

[15] G. Friesen and H. A. Ossenbrink, "Capacitance effects in high-efficiency cells," Solar Energy Materials and Solar Cells, vol. 48, pp. 77-83, 1997.

[16] H. Cesiulis, N. Tsyntsaru, A. Ramanavicius, and G. Ragoisha, "The study of thin films by electrochemical impedance spectroscopy," in
Nanostructures and Thin Films for Multifunctional Applications: Technology, Properties and Devices. Springer International Publishing, 2016.

[17] U. Mehmood, H. Z. Aslam, F. A. Al-Sulaiman, A. AlAhmed, S. Ahmed, M. I. Malik, and M. Younas, "Electrochemical impedance spectrscopy and photovoltaic analyses of dye-sensitized solar cells based on carbon $/ \mathrm{TiO}_{2}$ composite counter electrode," Journal of The Electrochemical Society, vol. 163, no. 5, pp. H339-H342, 2016

[18] J. J. Kim and Y. M. Young, "Study on the passive film of type 316 stainless steel," Int. J. Electrochem. Sci., vol. 8, pp. 11847-11859, 2013.

[19] M. Itagaki, "Principle and analytical method of impedance spectroscopy,”Surface Science (表面科学), vol. 33, no. 2, pp. 64-68, 2012.

[20] K. Takeno, M. Yamasaki, and S. Muroyama, "Equivalent circuit of a battery considering transient response and discharge characteristics," T. IEE Japan, vol. 118-B, no. 11, pp. 1256-1263, 1998.

[21] A. Nakahira, M. Tamai, K. Sakamoto and S. Yamaguchi, "Sintering and microstructure of porous hydroxyapatite," Journal of the Ceramic Society of Japan, vol. 108, no. 1, pp. 99-104, 2000. 


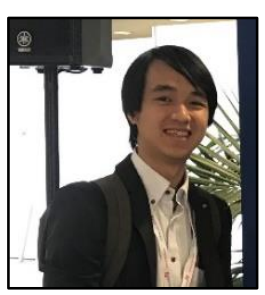

Htoo Nay Wunn was graduated from Myanmar Maritime University in 2014 and was conferred B.E in Marine Engineering. He joined Tokyo University of Marine Science and Technology (TUMSAT) as a research student in 2019. He was granted Master of Engineering degree in Marine Mechanical Engineering. He is currently studying Applied Marine Environment Studies to be entitled as Doctor of Engineering. He is an enthusiastic young researcher and his current research focused on electrochemistry, marine wet solar cells, and material analysis of copper oxides layer and stainless-steel substrates.

He got the Best Marine Engineer Award from Myanmar Maritime University in 2014 and the Poster Award from the 36th European Photovoltaic Solar Energy Conference in 2019.

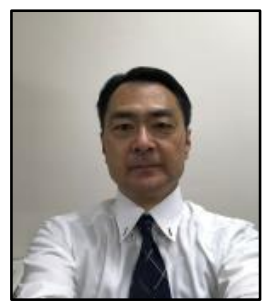

Professor Shinichi Motoda was born in Yamaguchi prefecture, Japan in 1962. He received the B.S. and M.S. degrees from Tokyo University of Mercantile Marine, in 1986 and the Ph.D. degree in mechanical engineering from University of Tokyo, in 2004. Since 2005, he has been a Professor in the Marine Electrical and Mechanical Engineering Department, Tokyo University of Marine Science and Technology and he performed as a Visiting professor in the University of Manchester, UK in 2006 and the University of Delaware, USA in 2014. He is the author of two books, more than 70 articles, and more than 4 inventions. His research interests include corrosion in the indoor atmosphere, microbial corrosion of stainless steel in seawater, corrosion protection of radio isotope catalysis, biofilm battery, and innovation photo-catalytic electrode for wet solar cells. In those research work, he holds two patents.

Prof. Motoda is a recipient of Paper Award from the Japan Society of Corrosion Engineering in 2001 and 2005, the Japan Institute of Marine Engineering in 2019, and the 36th European Photovoltaic Solar Energy Conference and Exhibition Poster Award in 2019.

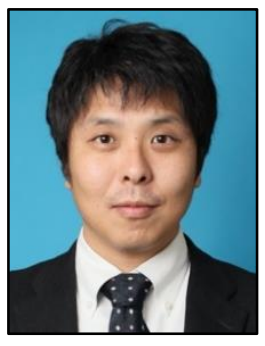

Motoaki Morita received the Doctor of Engineering in mechanical engineering from Yokohama National University, Kanagawa, JAPAN, in 2011.

From 2011 to 2018, he was an Assistant Professor with the Department of Marine Electronics and Mechanical Engineering, Tokyo University of Marine Science and Engineering. Since 2018, he has been an Associate Professor with the Department of Marine Electronics and Mechanical Engineering, Tokyo University of Marine Science and Engineering. His research interests include deformation mechanism of titanium alloys, corrosion and scaling at materials in geothermal power plant, mechanical propeties of galvanized steels. He holds two patents.

Dr. Morita was a recipient of the Japan Institute of Light Metals A Rising Star of Light Metals Prize, the Goethermal Research Society of Japan Research Encouragement Award in 2018, and the Japan Institute of Marine Engineering Lloyd Register Manson Prize in 2019, and 4 awards from the other academic associations.

Shinya Katayose, photograph and biography not available at the time of publication. 